\title{
Marchetti type of aircraft engine error detection system using hill climbing heuristic
}

\author{
Anton Setiawan Honggowibowo ${ }^{1, *}$, Asih Pujiastuti', Yuliani Indrianingsih ${ }^{3}$, Dhea Yogi Anugerah ${ }^{4}$ \\ ${ }^{1,2,3,4}$ Program Studi Informatika, Institut Teknologi Dirgantara Adisutjipto
}

\begin{tabular}{|c|c|}
\hline Article Info & ABSTRACT \\
\hline Article history: & $\begin{array}{l}\text { Transportation has become a human need today, one of which is air } \\
\text { transportation. namely airplanes. In order for the aircraft to be used }\end{array}$ \\
\hline Received June $2^{\text {nd }}, 2021$ & properly and comfortably, it is necessary to carry out routine \\
\hline Accepted June 7, 2021 & maintenance, especially before flying. Problems caused by aircraft \\
\hline Published June 8, 2021 & engines are sometimes small problems that do not require a high level \\
\hline Keywords: & knowledge of aircraft engines can do it. But sometimes these \\
\hline Aircraft Engine & problems also require a high level of expertise regarding these \\
\hline Expert System & Through this application, users can consult the system such as \\
\hline Heuristic Hill Climbing & consulting with experts to find out the symptoms that occur on the \\
\hline Fault Detection & $\begin{array}{l}\text { plane and find solutions to the problems encountered. The expert } \\
\text { system built using the Hill Climbing Heuristic method resulted in } \\
72.67 \% \text { when tested on respondents. }\end{array}$ \\
\hline
\end{tabular}

Corresponding Author:

Anton Setiawan Honggowibowo, Program Studi Informatika,

Institut Teknologi Dirgantara Adisutjipto,

J1. Janti Blok R, Lanud Adisutjipto, Yogyakarta, Indonesia

Email: *anton_s_h@yahoo.com

\section{INTRODUCTION}

Air transport is an important part of human life, the necessity of this transport is used to advance various aspects of life such as commerce, education, industry and social aspects. Airplanes are an option for some people who wish to visit or travel to a remote location to accomplish their work or travel agenda [1]. Airplanes will always be the good alternative as they can reach the most remote areas with a relatively short travel time. Therefore, good and comfortable aircraft conditions are necessary to reduce the risk of accidents [2].

Cases of airplane accidents will always be associated with several factors such as: human error, climate and engine. In order to reduce the risk of an airplane crash, an airline must perform maintenance on airplanes. Aircraft maintenance is not cheap, not only for damage detection equipment, but also for paying a technician or expert who can repair the damaged aircraft [3]. In addition to the high maintenance costs, the cost of training a technician is also expensive. Another problem with the limited capacity of a technician, namely the precision of a technician in tracing the problem of damage to the aircraft, there is a need for a system that can be used by a technician to aircraft to identify damage on the basis of existing data that is consistent with the symptoms of damage to the aircraft.

The system which can assist aircraft technicians and which has the capability or expertise of an expert in the field of aircraft is an expert system. An expert system is a computer program that contains the knowledge of one or more human experts in a specific area [4]. Many areas can be addressed by expert systems, including diagnosis of plant diseases and pests [5], pharmacy live plants for alternative medicine [6], dental disease expert systems [7], diseases digestive systems [8], education, machine tools [9], damage to vehicles such as cars [10], diagnostics of damage to other vehicles, including airplanes[11], etc. Several previous studies on expert systems that can help diagnose aircraft damage include a Landing Gear Damage 
Identification System on Cessna aircraft [12], an expert system for diagnosing damage on a Cessna Grand Caravan 208B [13], an equipment detection system used to assist work activity activities at airports that are often damaged due to the way the operator uses equipment that is not suitable [14]. Based on research on the performance analysis of the Marchetti SF-260 [15] aircraft, this study chose to use the Marchetti type aircraft test. Meanwhile, several heuristic methods that have been used to solve the problems are in the case of exam planning which is complex and time consuming when done manually [16] [17], and A Hybrid Meta-Heuristic Feature Selection Method for Identification of Indian Spoken Languages From Audio Signals[18]. As with previous research, namely Late Acceptance Hill Climbing Based Social Ski Driver Algorithm for Feature Selection [19] and application of the steepest climb method in games puzzle [20] applied the hill climbing method. In this study, we will build an expert engine damage / fault detection system on Marchetti-type airplanes by applying the Heuristic Hill Climbing method.

\section{RESEARCH METHOD}

The methods used in this research are:

1. Interview Method

The method is by conducting direct interviews with aircraft technicians / experts, namely Mr. Kris Haryanto ST.,MT. From the results of these interviews can be obtained an explanation of the symptoms and causes of damage to aircraft engines. This knowledge is then stored in the computer and used to build an expert system that can solve problems like an expert.

2. Library Method

Methods of collecting data by taking information from reference books and the internet.

3. Observation Method

The method of data collection is done by observing directly to the object of research to see closely the activities carried out. Observations were made to find out the implementation methods carried out by aircraft technicians in detecting engine damage on aircraft.

4. System Design Method

The method is to design an interface form for an expert system for detecting engine damage on aircraft.

5. Trial and Analysis Method

Testing the system in building an expert system for detecting engine damage on aircraft by applying the Heuristic Hill Climbing method.

\subsection{Metode Heuristic Hill Climbing}

Heuristic techniques are techniques used to speed up the search for solutions. Heuristic techniques are used to eliminate several possible solutions without having to explore them in full. In addition, heuristic techniques also help decide which possible solutions need to be evaluated first. There are several heuristic search methods, one of which is the hill climbing method. The hill climbing method is one of the many artificial intelligence methods to solve optimization problems. The way the Hill Climbing method algorithm works is as follows:

1. Starting from the initial state, perform the test. If it is a goal, then stop. And if not, continue with the current state as the initial state.

2. Do it until the goal is achieved.

a. Determine the destination based on the best heuristic value of the existing nodes.

b. Do this for each node used by the current state.

c. Use those nodes and form a new state.

d. Evaluate the new situation. If it is the goal (result), exit. If not, compare the heuristic values with other nodes. If better, make the value of the new state heuristic the goal.

e. If the goal is better than the current state heuristic value, change the goal to the current state. An image of the search process can be seen in Figure 1. 


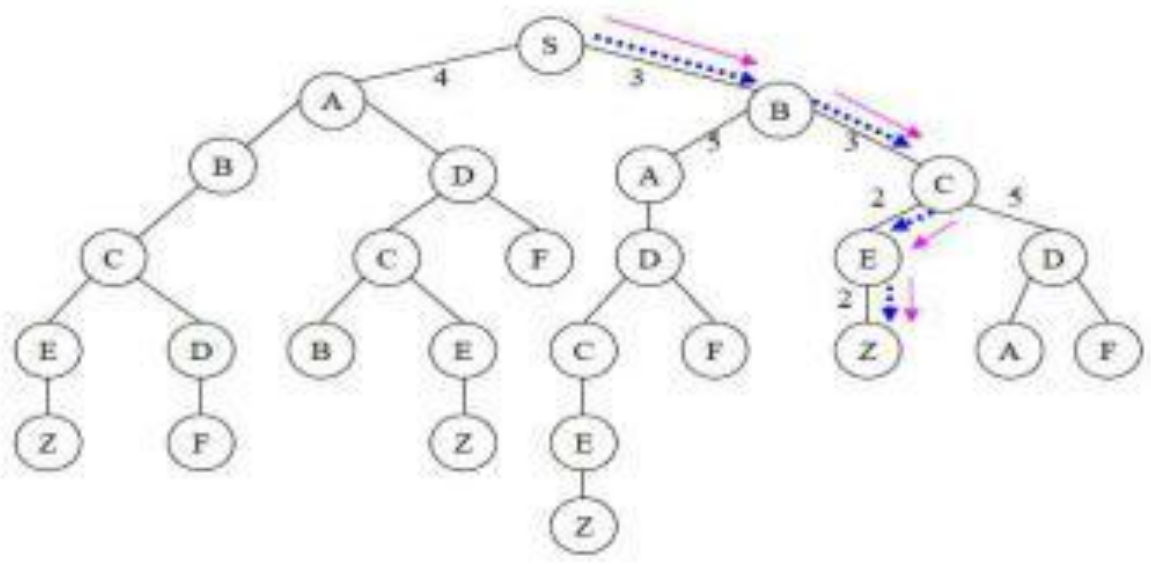

Figure 1. Search Process With Hill Climbing

\subsection{Symptoms of Damage to Aircraft Engines}

Damage to aircraft can occur due to various things, in this study the symptoms of damage to aircraft can be described as shown in table 1, namely the table of symptoms of aircraft engine damage.

Table 1. Aircraft Damage Symptoms Table

\begin{tabular}{|c|c|c|}
\hline Symptom & Name Symptom & Question \\
\hline G001 & The instrument turns on when on & $\begin{array}{l}\text { The instrument cluster turns on when contact } \\
\text { position on }\end{array}$ \\
\hline G002 & Contact starting position & $\begin{array}{l}\text { When contact the position start what rotating } \\
\text { starter dynamo }\end{array}$ \\
\hline G003 & Cable plus minus battery & Is the +- cable to the battery properly attached? \\
\hline G004 & Instrument cluster flashing & $\begin{array}{l}\text { Is the instrument cluster flashing when the } \\
\text { dynamo starter rotates }\end{array}$ \\
\hline G005 & Bendix dynamo starter & Does bendix work when position start \\
\hline G006 & ACC fuse / relay & Is the $\mathrm{AC}$ fuse/relay normal? \\
\hline G007 & Machine can't start & Will the engine start when start \\
\hline G008 & Idle RPM & Is the RPM stable immediately \\
\hline G009 & Spark plugs and spark plug wires & $\begin{array}{l}\text { Are the spark plugs and spark plug wires inside } \\
\text { good condition }\end{array}$ \\
\hline G010 & The machine vibrates & At high RPM does the engine vibrate \\
\hline G011 & Ignition timing & Whether the ignition timing is correct \\
\hline G012 & engine mount & Is the engine mount broken? \\
\hline G013 & Carburetor / injector & Is the carburetor/injector in good condition? \\
\hline
\end{tabular}

Table 1 is a table of symptoms of damage to aircraft engines, in this study there were 13 symptoms of damage to aircraft.

\subsection{Types of Damage to the Aircraft}

Damage to aircraft engines occurs due to various symptoms. Symptoms of the damage that resulted in damage to the aircraft. The damage to the aircraft can be seen in table 2 .

Table 2. Table of Types of Damage to Aircraft

\begin{tabular}{cll}
\hline $\begin{array}{c}\text { ID } \\
\text { Damage }\end{array}$ & \multicolumn{1}{c}{ Name Damage } & \multicolumn{1}{c}{ Solution } \\
\hline K001 & Battery cable & Cable + - is damaged \\
K002 & The starter dynamo is broken & Change starter dynamo \\
K003 & The starter dynamo bendix is faulty & Change bendix
\end{tabular}




\begin{tabular}{lll} 
K004 & Battery damaged & Change the battery \\
K005 & The AC relay fuse is faulty & Replace the ACC fuse/relay \\
K006 & Defective spark plugs or ignition wire & Replace spark plugs and spark plug wires \\
K007 & Ignition timing incorrectly & Adjust ignition timing \\
K008 & Cracked engine mount & Replace engine mounting \\
K009 & Defective mount bushing & Replace the mounting bushings \\
K010 & Mixture is too rich or too lean & Adjust the fuel and air mixture settings \\
K011 & Carburetor, injection & Clean or replace the injector carburetor \\
\hline
\end{tabular}

Table 2 is a table of types of damage to aircraft that have been inputted into the system. There are 11 types of damage to aircraft that exist in the aircraft engine damage detection expert system.

\subsection{Table of Relation of Types of Damage to Symptoms on Aircraft}

Damage to aircraft engines occurs due to various symptoms. Symptoms of the damage that resulted in damage to the aircraft. The damage to the aircraft can be seen in table 3 .

Table 3. Table of Damage Relationship with Symptoms on Aircraft

\begin{tabular}{|c|c|c|c|}
\hline $\begin{array}{c}\text { Id } \\
\text { Damage }\end{array}$ & Damage Name & Symptoms & Solution \\
\hline K001 & Battery cable & $\begin{array}{l}\text { G001 } \\
\text { G002 } \\
\text { G003 } \\
\text { G004 }\end{array}$ & Cable +- is damaged \\
\hline K002 & $\begin{array}{l}\text { The starter dynamo is } \\
\text { broken }\end{array}$ & $\begin{array}{l}\text { G001 } \\
\text { G002 } \\
\text { G004 }\end{array}$ & Change starter dynamo \\
\hline K003 & $\begin{array}{l}\text { The starter dynamo bendix is } \\
\text { faulty }\end{array}$ & $\begin{array}{l}\text { G001 } \\
\text { G002 } \\
\text { G003 }\end{array}$ & Change bendix \\
\hline K004 & Battery damaged & $\begin{array}{l}\text { G001 } \\
\text { G003 } \\
\text { G006 }\end{array}$ & Change the battery \\
\hline K005 & The AC relay fuse is faulty & $\begin{array}{l}\text { G001 } \\
\text { G003 } \\
\text { G006 }\end{array}$ & Replace the ACC fuse/relay \\
\hline K006 & $\begin{array}{l}\text { Defective spark plugs or } \\
\text { ignition wire }\end{array}$ & $\begin{array}{l}\text { G001 } \\
\text { G002 } \\
\text { G004 } \\
\text { G007 } \\
\text { G009 }\end{array}$ & $\begin{array}{l}\text { Replace spark plugs and spark } \\
\text { plug wires }\end{array}$ \\
\hline K007 & Ignition timing incorrectly & $\begin{array}{l}\text { G001 } \\
\text { G002 } \\
\text { G004 } \\
\text { G007 } \\
\text { G008 } \\
\text { G009 } \\
\text { G011 }\end{array}$ & Adjust ignition timing \\
\hline K008 & Cracked engine mount & $\begin{array}{l}\text { G001 } \\
\text { G002 } \\
\text { G004 } \\
\text { G007 } \\
\text { G008 } \\
\text { G010 } \\
\text { G012 }\end{array}$ & Replace engine mounting \\
\hline K009 & Defective mount bushing & $\begin{array}{l}\text { G001 } \\
\text { G002 } \\
\text { G004 }\end{array}$ & $\begin{array}{l}\text { Replace the mounting } \\
\text { bushings }\end{array}$ \\
\hline
\end{tabular}




\begin{tabular}{|c|c|c|c|}
\hline & & G007 & \\
\hline & & G008 & \\
\hline & & G010 & \\
\hline & & G012 & \\
\hline K010 & Mixture is too rich or too & G001 & Adjust the fuel and air mixture \\
\hline & lean & G002 & settings \\
\hline & & G004 & \\
\hline & & G007 & \\
\hline & & G009 & \\
\hline & & G011 & \\
\hline K011 & Carburetor, injection & G001 & Clean or replace the injector \\
\hline & & G002 & carburetor \\
\hline & & G004 & \\
\hline & & G007 & \\
\hline & & G009 & \\
\hline & & G011 & \\
\hline & & G013 & \\
\hline
\end{tabular}

Table 3 is a table of types of damage to the aircraft. There are 11 types of damage to aircraft that exist in the aircraft engine damage detection expert system. In this table there are also symptoms that arise from a malfunction that occurs in the aircraft engine.

\subsection{Hill Climbing Method Diagnostic Process Flowchart}

The following is a description of the flowchart design for the diagnostic process of the hill climbing method on an expert system for detecting aircraft engine damage using the hill climbing heuristic as shown in Figure 2. Here is the description:

1. The user performs a diagnosis by answering questions about the symptoms of damage.

2. $\quad$ Checking the appropriate rules.

3. If a suitable fault is found, it will display the type of damage, otherwise it will be forwarded/returned to the next symptom question.

4. Done.

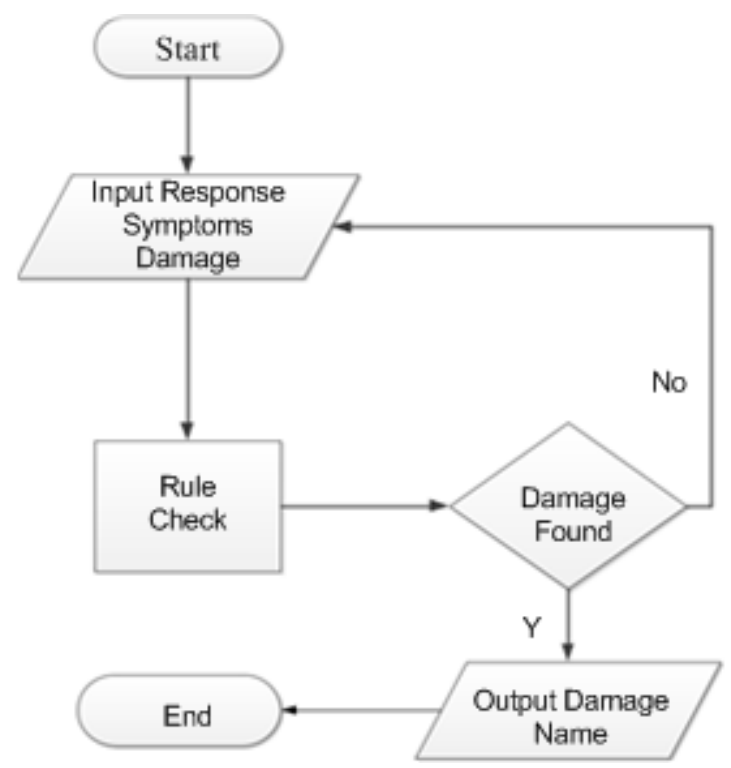

Figure 2. Program Flowchart

\section{RESULTS AND ANALYSIS}

Based on the analysis of the system design that has been carried out, a damage detection system has been implemented using the heuristic hill climbing method to detect engine damage on aircraft. The implementation of this system aims to detect damage to aircraft. 


\subsection{Process Menu Implementation}

Implementation of the Process Menu is a display that is used to carry out the process of the Hill Climbing method, before carrying out the process of diagnosing damage, the user is required to select the aircraft that will be checked for the engine. The process menu display can be seen in Figure 3.

\section{Home Data Master Logout}

\section{Fault Diagnostic Process}
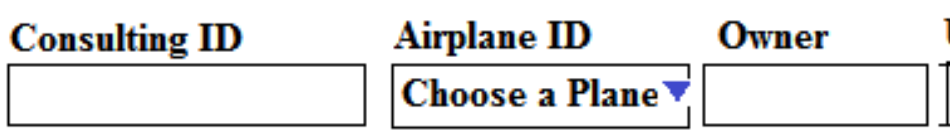

User Consultation Date

\section{Consultation Process}

Figure 3. Process Menu Display

\subsection{Binary Tree Function Test}

In testing the binary tree function, initial symptoms will be included which will be used as the first step for inspection on aircraft. Binary tree search flow using the Heuristic Hill Climbing method according to the cases that were solved at the application function test stage can be shown in Figure 4.

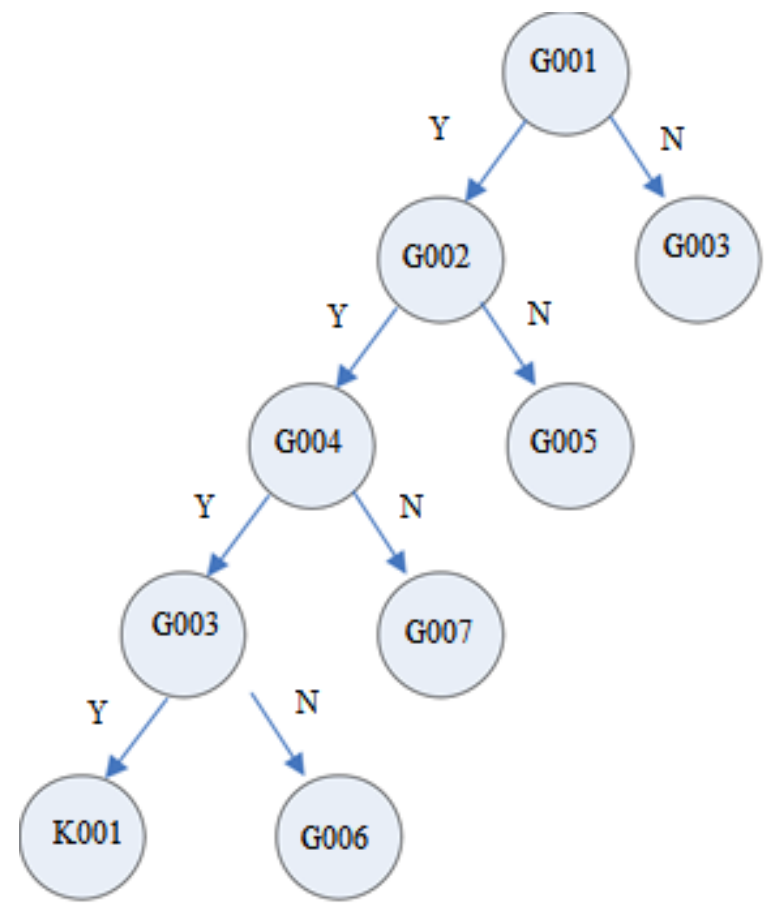

Information :

Figure 4. Fault Diagnostic Flow

G00x : Symptom ID

K00x : Damage ID

Can be seen in Figure 3. G001 is an early symptom that should be checked. In this binary tree function the Heuristic Hill Climbing method is used, so it can be seen in Figure 3. The process goes down until a fault is found. The picture shows that the damage has been found after the 4th symptom question. In the fourth symptom question, it can be seen that there is a similarity with the second question on the left, 
namely G003, using the Heuristic Hill Climbing method, it is not allowed to go back up so that the iteration will continue down until find a solution.

\subsection{Discussion}

Based on the results of application testing and binary tree testing, it can be seen that the diagnosis of damage using the Heuristic Hill Climbing method can be used to determine the damage that occurs to aircraft engines by using questions that arise from the symptoms experienced by the engine more quickly because the process only explores possibilities. from the symptoms experienced only and eliminate some of the possible symptoms that are not experienced until the type of damage is found.

\subsection{User Trial}

User trials were conducted using a questionnaire which involved 30 aeronautical engineering students. The forms of questions used in the questionnaire are as follows:

Give your opinion regarding the use of the Aircraft Engine Damage Detection Expert System application using the Heuristic Hill Climbing Method (1 is the lowest rating to 4 the highest rating).

$\begin{array}{llllll}1 & \text { Interface (Display) Program } & 1 & 2 & 3 & 4 \\ 2 & \text { Ease of use } & 1 & 2 & 3 & 4 \\ 3 & \text { Clarity of information and data } & 1 & 2 & 3 & 4 \\ 4 & \text { Program Use } & 1 & 2 & 3 & 4 \\ 5 & \text { Overall Program Assessment } & 1 & 2 & 3 & 4\end{array}$

Table 4. Questionnaire Results

\begin{tabular}{llcccc}
\hline No & \multicolumn{1}{c}{ Questionnaire } & \multicolumn{3}{c}{ Total Value } \\
& & 1 & 2 & 3 & 4 \\
\hline 1 & Interface (Display) Program & 0 & 1 & 23 & 5 \\
2 & Ease of use & 0 & 4 & 21 & 3 \\
3 & Clarity of information and data & 0 & 3 & 24 & 10 \\
4 & Program Use & 0 & 3 & 17 & 6 \\
5 & Overall Program Assessment & 0 & 0 & 24 & 30 \\
& Total & 0 & 11 & 109 & $20 \%$ \\
& Percentage & $0 \%$ & $7,33 \%$ & $72,67 \%$ & $2 \%$ \\
\hline
\end{tabular}

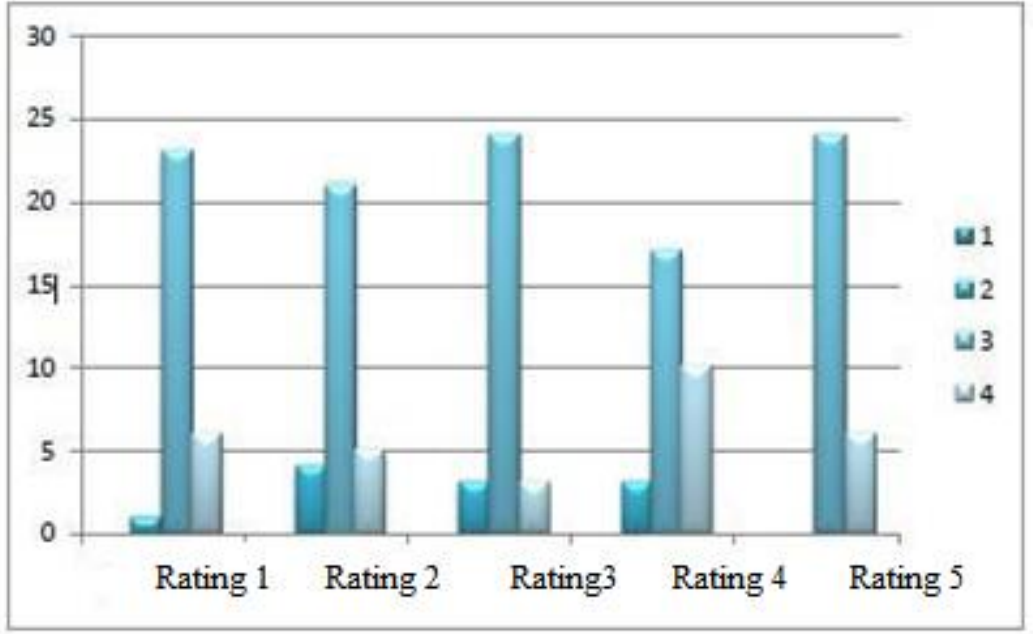

Figure 5. Diagram of the Percentage of Questionnaire Results

By using the questionnaire data that has been obtained, the percentage value of 1 is $0 \%$, the value of 2 is $7.33 \%$, the value of 3 is $72.67 \%$, and the value of 4 is $20 \%$. The calculation is done by adding up the value data on the questionnaire obtained from 30 students, then the sum of each value is divided by 150 . The value of 150 is obtained by multiplying the 30 questionnaire data with the 5 available questions. From the addition process like this, so that the percentage of each value is obtained which is then made into a diagram. 


\section{CONCLUSION}

1. This application is designed to be useful to make it easier to find damage to aircraft engines, so that aircraft repair times can be shortened so that the aircraft can immediately return to the air.

2. The results of the application test and binary tree test show the conclusion that the damage diagnosis application using the Heuristic Hill Climbing method can provide information about the damage that has occurred to an aircraft.

3. The test results of 30 respondents on the application of an expert system for detecting engine damage on aircraft using the Heuristic Hill Climbing method are $72.67 \%$.

\section{REFERENCES}

[1] Kusumaningsih, A., Dewanti, D., \& Muthohar, I, "Airspace Capacity Analysis of Adisutjipto Airport", Angkasa: Jurnal Ilmiah Bidang Teknologi, vol. 12, no. 2, pp. 127-134, 2020.

[2] Nur Zuraini, "Sistem Pendukung Keputusan Uji Kelayakan Pesawat Terbang Dengan Metode Fuzzy Tsukamoto Pada PT. GFM Aeroasia TBK", Jurnal Pelita Informatika, vol. 9, no. 4, April 2021.

[3] Russell Belk, "Machines and Artificial Intelligence", Journal of Marketing Behavior: Vol. 4: No. 1, pp $11-30,2019$.

[4] Kursini, "Konsep Dan Aplikasi Sistem Pendukung Keputusan”, Yogyakarta: Andi, 2017.

[5] Pati, M., Defit, S., \& Nurcahyo, G, "Sistem Pakar dengan Metode Forward Chaining untuk Diagnosis Penyakit dan Hama Tanaman Semangka", Jurnal Sistim Informasi Dan Teknologi, vol. 2, no. 4, pp. 102 107, December 31, 2020.

[6] Satriadi, D., Honggowibowo, A., \& Indrianingsih, Y., "Sistem Pakar Pada Tanaman Apotik Hidup Untuk Pengobatan Alternatif Menggunakan Metode Certainty Factor”, Compiler, vol. 6, no. 2, 2017.

[7] Yansyah, I., \& Sumijan, "Sistem Pakar Metode Forward Chaining untuk Mengukur Keparahan Penyakit Gigi dan Mulut", Jurnal Sistim Informasi Dan Teknologi, vol.3, no.2, pp. 41-47, June 30, 2021.

[8] Silmina, E., \& Hardiani, T., "Design of Expert System Diarrhea for Toddler Using K-Nearest Neighbor Algorithm (K-NN)", Conference SENATIK STT Adisutjipto Yogyakarta, vol. 4, pp. AI211-218, 2018.

[9] X. Xu, X. Yan, C. Sheng, C. Yuan, D. Xu and J. Yang, "A Belief Rule-Based Expert System for Fault Diagnosis of Marine Diesel Engines," IEEE Transactions on Systems, Man, and Cybernetics: Systems, vol. 50, no. 2, pp. 656-672, Feb. 2020.

[10] S. A. Mostafa, A. Mustapha, A. A. Hazeem, S. H. Khaleefah and M. A. Mohammed, "An Agent-Based Inference Engine for Efficient and Reliable Automated Car Failure Diagnosis Assistance," IEEE Access, vol. 6, pp. 8322-8331, 2018.

[11] A. Ayuningtyas, A. S. Honggowibowo, S. Mulyani and A. Priadana, "A Web-Based Aircraft Maintenance Learning Media to Support Learning Process in Aerospace Engineering Education during the COVID-19 Pandemic," Sixth International Conference on e-Learning (econf), , pp. 55-60, 2020.

[12] ANGGORO, Annga Ardi, "Identification of Damage Gear Landing System of Cessna Aircraft", Vortex, vol. 2, no. 1, p. 39 - 50, apr, 2021.

[13] Rianto, Rianto, "Sistem Pakar Diagnosa Permasalahan Pada Pesawat Cessna Grand Caravan 208B Menggunakan Metode Backward Chaining", Angkasa: Jurnal Ilmiah Bidang Teknologi, vol. 8, no. 2, pp 129-138, 2016.

[14] Andriana Manik and Fricles A Sianturi, "Sistem Pakar Mendeteksi Kerusakan Pada Equipment Dengan Menggunakan Metode Forward Chaining”, JIKOMSI, vol. 3, no. 3, pp. 183-191, Jan. 2021.

[15] Bismil Rabeta, "Analisis Performa Engine Marchetti SF 260", Jurnal Teknologi Kedirgantaraan, vol. 4, no. 4, Juli 2019.

[16] G. Icasia, R. Tyasnurita, and E. S. Purba, "Application of Heuristic Combinations in Hyper-Heuristic Framework for Exam Scheduling Problems", RESTI, vol. 4, no. 4, pp. 664 - 671, Aug. 2020.

[17] Supoyo, V., \& Muklason, A., "Pendekatan Hyper Heuristic Dengan Kombinasi Algoritma Pada Examination Timetabling Problem", ILKOM Jurnal Ilmiah, vol. 11, no. 1, pp. 34-44, 2019.

[18] A. Das, S. Guha, P. K. Singh, A. Ahmadian, N. Senu and R. Sarkar, "A Hybrid Meta-Heuristic Feature Selection Method for Identification of Indian Spoken Languages From Audio Signals," IEEE Access, vol. 8, pp. 181432-181449, 2020.

[19] B. Chatterjee, T. Bhattacharyya, K. K. Ghosh, P. K. Singh, Z. W. Geem and R. Sarkar, "Late Acceptance Hill Climbing Based Social Ski Driver Algorithm for Feature Selection," IEEE Access, vol. 8, pp. 75393-75408, 2020.

[20] Anam, H., Hanafi, F., Adifia, A., Ababil, A., \& Bukhori, S. "Penerapan Metode Steepest Ascent Hill Climb pada Permainan Puzzle", INFORMAL: Informatics Journal, vol. 3, no. 2, pp. 36-40, 2018. 